\title{
Study of 448 cases of melanoma in situ in two hospitals in Rio de Janeiro*
}

\section{Luciana Pantaleão ${ }^{1}$}

\author{
Mayra Carrijo Rochael ${ }^{1}$
}

\section{DOI: http://dx.doi.org/10.1590/abd1806-4841.20175121}

\begin{abstract}
The diagnosis of cutaneous melanoma in situ, considered to have excellent prognosis, has been increasingly frequent, with rare isolated reports of cutaneous melanoma in situ presenting recurrence, metastasis, and death. No specific study is found in the literature about these lesions of unexpected behavior. We describe the demographic and histopathological findings of 448 cases of cutaneous melanoma in situ in 369 patients, emphasizing the prognostic criteria of those with unfavorable outcomes, corresponding to 9 cases in which regression had no significant role. Adnexotropism was found in $44.5 \%$ of cases. The study of early lesions would allow clinicians to have a better understanding of the evolutionary processes of the disease. Keywords: Melanoma; Prognosis; Neoplasm metastasis; Neoplasm recurrence, local; Recurrence
\end{abstract}

The diagnosis of cutaneous melanoma in situ (MIS), considered to have excellent prognosis, has been increasingly frequent, with rare isolated reports presenting recurrence, metastasis, and death. No reports are found in the literature about specific studies on melanoma in situ with unfavorable behavior. ${ }^{1,2,3}$ In this report, we describe demographic and histopathological findings of MIS cases, with emphasis on the prognostic criteria of those with unfavorable evolution. We identified cases of MIS in two institutions in Rio de Janeiro - a general hospital and an oncology center - between the years 1998 and 2010. We gathered demographic and histopathological information on 448 lesions in 369 patients. The number of diagnosed lesions increased over the years (from 17 in 1998 to 70 in 2010). We observed a female predilection $(57.45 \%)$, and ages ranged between 3 and 94 years, with a mean age of 55 years. 48 patients had more than one primary lesion. The predominant topography was the trunk, both in males (40.86\%) and females (40.08\%). Although we found apparent epidemiological similarity between the cases of both institutions, the large difference in the number of patients makes the comparison difficult, since 337 out of 369 patients came from the oncology center. To date, 9 patients $(2.01 \%)$ presented with unfavorable evolutions, all adults (31-80 years) with primary head, neck, or feet involvement. Of these nine, five had local recurrence, three evolved with regional metastasis, and one of them developed distant metastases. Disease-free survival (DFS) ranged from 6-121 months, averaging 48 months: 46 months in cases with local recurrence and 51 in cases with metastases (Table 1). Among these nine cases, two of them had more than one primary lesion: in case 148, two melanomas in situ were simultaneously removed from the right and left feet. In case 441, a melanoma in situ on the left arm had been previously diagnosed. We observed regression in late-stage lesion in one of the nine cases; adnexotropism in 4; and one of them showed expansive junctional nests (Figure 1). The topographic distribution of lesions in women (mostly on the trunk) differs from that found in the literature. ${ }^{4,5}$ We highlight the occurrence of 9 patients with un-

TABLE 1: Key demographic and histopathological findings of nine melanomas in situ with unfavorable evolution

\begin{tabular}{|c|c|c|c|c|c|c|c|c|c|c|}
\hline $\begin{array}{l}\text { Case } \\
\text { No. }\end{array}$ & Sex & Age & Topography & Histological Type & $\begin{array}{l}\text { Inflammatory } \\
\text { Infiltrate }\end{array}$ & $\begin{array}{l}\text { Expansive } \\
\text { Nests }\end{array}$ & Anexotropism & Regression & Evolution & Dfs \\
\hline 108 & Male & 76 & Head \& Neck & Lentigo Maligna & Inactive & Absent & Absent & Absent & Recurrence & 27 Months \\
\hline 112 & Female & 60 & Head \& Neck & Extensive Superficial & Inactive & Absent & Present & Absent & Regional Metastasis & 50 Months \\
\hline 148 & Female & 40 & Lower Limb & Acral Lentiginous & Active & Absent & Absent & Absent & Recurrence & 61 Months \\
\hline 158 & Male & 55 & Head \& Neck & Extensive Superficial & Active & Absent & Present & Absent & Regional Metastasis & 129 Months \\
\hline 191 & Female & 68 & Lower Limb & Acral Lentiginous & Inactive & Absent & Absent & Late Stage & Regional Metastasis & 20 Months \\
\hline 248 & Male & 65 & Head \& Neck & Lentigo Maligna & Absent & Absent & Absent & Absent & Recurrence & 31 Months \\
\hline 294 & Male & 80 & Head \& Neck & Extensive Superficial & Active & Present & Present & Early Stage & Recurrence & 61 Months \\
\hline 329 & Female & 31 & Head \& Neck & Extensive Superficial & Active & Absent & Absent & Absent & Distant Metastasis & 6 Months \\
\hline 441 & Female & 74 & Head \& Neck & Lentigo Maligna & Inactive & Absent & Present & Absent & Recurrence & 50 Months \\
\hline
\end{tabular}

Received on 11.09.2015

Approved by the Advisory Board and accepted for publication on 19.02.2016

* Work performed at Instituto Nacional do Câncer (INCA) and Universidade Federal Fluminense (UFF) - Niterói (RJ), Brazil.

Financial support: none.

Conflict of interest: none.

1 Department of Pathology - Universidade Federal Fluminense (UFF) - Niterói (RJ), Brazil.

C2017 by Anais Brasileiros de Dermatologia 

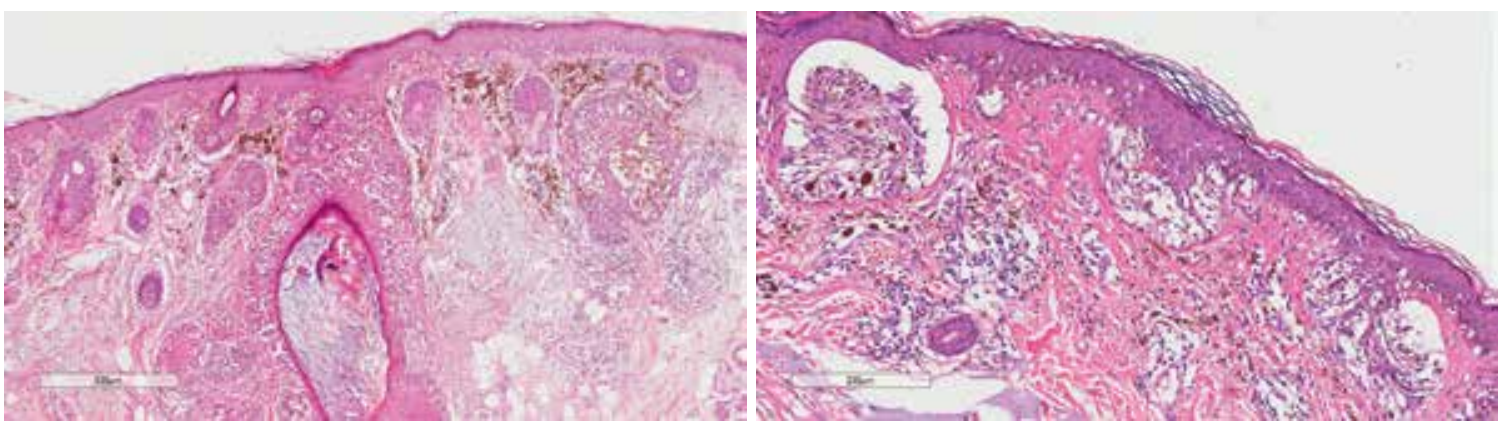

Figure 1: Case No. 112 - Melanoma in situ with extensive tropism for adnexal structures that developed regional metastasis. Case No. 294 Melanoma in situ with expansive junctional nests; the case presented local recurrence.

favorable evolution, in which the regression had no significant role. Tropism for adnexal structures was found in $44.5 \%$ of cases (this finding was observed in $31.9 \%$ of cases with favorable outcome), and junctional expansive nests in one case. ${ }^{6,7}$ Among the cases of melanoma in situ with an unfavorable evolution, it seems that adnexotropism contributes to this behavior, as regression and junctional expansive nests were isolated findings. However, the evaluation of more cases is needed to better understand the evolutionary processes of the disease and to reduce morbidity and mortality rates. $\square$

\section{REFERENCES}

1. Ronan SG, Eng AM, Briele HA, Shioura NN, Das Gupta TK. Thin malignant melanomas with regression and metastases. Arch Dermatol. 1987;123:1326-30.

2. Guitart J, Lowe L, Piepkorn M, Prieto VG, Rabkin MS, Ronan SG, et al. "Histological characteristics of metastasizing thin melanomas - a Case-control Study of 43 Cases." Arch Dermatol. 2002;138:603-8.

3. Megahed M, Schön M, Selimovic D, Schön MP. "Reliabiliy of diagnosis of melanoma in situ". Lancet. 2002;359:1921-2.

4. Mckee P, CalonjE E, Scott GR. Pathology of the skin with clinical correlations Boston: Elsevier; 2012.

5. Barnhill RL, Piepkorn M, Busam KJ. Pathology of melanocytic nevi and malignant melanoma. New York: Springer; 2014

6. Piris A, Mihm MC Jr. "Progress in melanoma histopathology and diagnosis." Hematol Oncol Clin North Am. 2009;23:467-80, viii.

7. Kutzner H, Metzler G, Argenyi Z, Requena L, Palmedo G, Mentzel T, et al. Histological and genetic evidence for a variant of superficial spreading melanoma composed predominantly of large nests. Mod Pathol. 2012;25:838-45.

\author{
MAILING ADDRESS: \\ Luciana Pantaleão \\ Rua Marquês do Paraná, 303 - Centro \\ 24033-900 - Niterói, RJ \\ Brazil \\ E-mail:lupantaleao@yahoo.com.br
}

How to cite this article: Pantaleão L, Rochael MC. Study of 448 cases of melanoma in situ in two hospitals in Rio de Janeiro. An Bras Dermatol. 2017;92(2):277-8. 